Review

\title{
DNA Minor Groove Binders-Inspired by Nature
}

\author{
Abedawn I. Khalaf, ${ }^{1, *}$ Ahmed A. H. Al-Kadhimi ${ }^{2}$ and Jaafar H. Ali ${ }^{3}$ \\ ${ }^{1}$ Research Officer, WestCHEM, Department of Pure \& Applied Chemistry, University of Strathclyde, Thomas Graham Buil- \\ ding, 295 Cathedral Street, Glasgow G1 1XL, United Kingdom \\ ${ }^{2}$ College of Science, Department of Chemistry, University of Tikrit, Tikrit, Iraq \\ ${ }^{3}$ Department of Chemistry, College of Science, Karbala University, Karbala, Iraq \\ * Corresponding author: E-mail: abedawn.khalaf@strath.ac.uk
}

Received: 29-07-2016

\begin{abstract}
The synthesis and biological activity of a variety of analogues to the naturally occurring antibacterial and antifungal Distamycin A were explored by a number of authors. These compounds were subject to a large array of assays. Some of these compounds showed high activity against a range of Gram-positive, Gram-negative bacteria as well as fungi. To explore the anti-parasitic activity of this class of compounds, specific modifications had to be made. A number of these compounds proved to be active against Trypanosoma brucei. The binding of a number of these compounds to short sequences of DNA were also examined using footprinting assays as well as NMR spectroscopy. Computer modelling was employed on selected compounds to understand the way these compounds bind to specific DNA sequences. A large number of variations were made to the standard structure of Distamycin. These changes involved the replacement of the pyrrole moieties as well as the head and tail groups with a number of heterocyclic compounds. Some of these minor groove binders (MGBs) were also investigated for their capability for the treatment of cancer and in particular lung cancer.
\end{abstract}

Keywords: Minor Groove Binders (MGB), Distamycin, Netropsin, Antibacterial, Thiazotropsin A, Clostridium difficile

\section{Introduction}

Minor Groove Binders (MGBs) is a large family of compounds called Lexitropsins which bind to the minor groove of the DNA (deoxyribonucleic acid) and are thus DNA binding ligands. ${ }^{1-22}$ This binding can vary from one molecule to another depending on the variations made on the MGBs. The first two compounds discovered were Distamycin A and Netropsin. Distamycin A is a naturally occurring antibiotic which was isolated in 1962 from the cultures of Streptomyces distallicus. These were found to be active against a variety of viruses, Gram-positive bacteria and protozoa. However, some of these were inactive as antitumor agents. The structure of Distamycin (Scheme 1) shows the presence of an oligopeptidic pyrrolecarbamoyl structure ending with an amidino moiety. Distamycin A reversibly binds to the minor groove of DNA by hydrogen bonds, van der Waals contacts and electrostatic interactions. These have a strong preference for adenine-thymine (AT) rich sequences containing at least four AT base pairs. ${ }^{23}$
If the number of pyrrole rings in an MGB increases to four, the activity will increase to around 20-fold compared to Distamycin A. This will also lead to an increase in the sequence specificity for longer tracts of AT-rich DNA and this is as a consequence of the greater availability of hydrogen bonding and van der Waals surface interactions.

Aleksic et al. ${ }^{59}$ explored the field of minor groove binders by incorporating organic compounds, such as mitomycin $\mathrm{C}$ and anthramycin, and inorganic compounds, such as cisplatin, in their studies. While Vafazadeh et al. ${ }^{60}$ reported the interaction of copper(II) complexes with DNA. Alcohol containing netropsin type symmetrical compounds were successfully prepared by Khan et al. ${ }^{61}$ They also managed to construct various unsymmetrical triaryl compounds and further explored the activity of these compounds. Others ${ }^{62}$ have studied a number of small indole derivatives for their DNA binding ability using fluorescence quenching experiments as well as molecular docking techniques. 


\section{Discussion}

The naturally occurring compounds Distamycin and Netropsin (Scheme 1) are the most studied compounds in this field. In our earlier studies we modified the MGBs by introducing various alkyl groups on the pyrrole nitrogen as well as C-alkyl substitution and this meant leaving the head group as in the naturally occurring compound. However, the tail group was replaced with dimethylaminopropyl (DMAP) $)^{50}$ These compounds (Scheme 2) show a number of examples of the MGBs which bind to the minor groove in a ratio of either $2: 1$ or 1:1 depending on the alkyl bulky<smiles>Cn1ccc(NC(=O)c2cc(NC(=O)c3cc(NC(=O)c4cc(NCCC(=N)N)cn4C)cn3C)cn2C)c1</smiles>

1 Distamycin A<smiles>Cn1cc(NC(=O)CNC(=N)N)cc1C(=O)NCCC(=N)N</smiles>

2 Netropsin

Scheme 1. The structure of DNA minor groove binders: Distamycin A and Netropsin<smiles></smiles>

\begin{tabular}{rll}
\hline 3 & R1 = R2 = R3 = Me; R4 $=\mathbf{H}$ & $\mathbf{2}$ to 1 \\
4 & $\mathrm{R} 1=\mathrm{R} 3=\mathrm{Me} ; \mathrm{R} 2=\mathrm{Et} ; \mathrm{R} 4=\mathrm{H}$ & 2 to 1 \\
5 & $\mathrm{R} 1=\mathrm{R} 3=\mathrm{Me} ; \mathrm{R} 2=$ isppropyl; $\mathrm{R} 4=\mathrm{H}$ & 2 to 1 \\
6 & $\mathrm{R} 1=\mathrm{R} 3=\mathrm{Me} ; \mathrm{R} 2=$ Cyclopentyl $; \mathrm{R} 4=\mathrm{H}$ & 2 to 1 \\
7 & $\mathrm{R} 1=\mathrm{R} 3=\mathrm{Me} ; \mathrm{R} 2=$ Cyclopropyl $\mathrm{R} 4=\mathrm{H}$ & 2 to 1 \\
8 & $\mathrm{R} 1=\mathrm{R} 3=$ isopropyl; $\mathrm{R} 2=\mathrm{Me} ; \mathrm{R} 4=\mathrm{H}$ & 1 to 1 \\
9 & $\mathrm{R} 1=\mathrm{R} 3=\mathrm{Me} ; \mathrm{R} 2=$ isopentyl; $\mathrm{R} 4=\mathrm{H}$ & 2 to 1 \\
10 & $\mathrm{R} 1=\mathrm{R} 2=\mathrm{R} 3=$ isopropyl $\mathrm{R} 4=\mathrm{H}$ & Weak Binding \\
11 & $\mathrm{R} 1=\mathrm{R} 2=\mathrm{R} 3=$ isopentyl; $\mathrm{R} 4=\mathrm{H}$ & No Binding \\
12 & $\mathrm{R} 1=\mathrm{R} 2=\mathrm{R} 3=\mathrm{R} 4=\mathrm{Me}$ & No Binding \\
\hline
\end{tabular}

Scheme 2. Compounds synthesised and studied together with their binding to the sequence AAATTATATTAT as measured by CE (reprinted with permission from J. Med. Chem., 2004, 47, 2133. Copyright 2004 American Chemical Society).

Table 1. Antibacterial and antifungal activity of selected compounds

\begin{tabular}{|c|c|c|c|c|c|c|c|c|c|c|c|}
\hline \multicolumn{5}{|c|}{ Antibacterial activity (MIC, $\mathrm{M} \times \mathbf{1 0}^{6}$ ) } & \multicolumn{7}{|c|}{ Antifungal activity $\left(\mathrm{MIC}, \mathrm{M} \times 10^{6}\right)$} \\
\hline compound & S. aur & S. fae & MRSA & E. clo & M. for & K. aer & P. vul & E. col & A. nig & A. nid & C. alb \\
\hline 3 & 10.0 & 0.31 & na & na & na & 164 & na & na & na & na & na \\
\hline 5 & na & 157 & 157 & na & na & 39.1 & 157 & na & 157 & na & $\mathrm{Na}$ \\
\hline 6 & 75.0 & 75.0 & 75.3 & na & 75.3 & na & na & na & 37.6 & $\mathrm{nt}$ & 75.3 \\
\hline 7 & 153.0 & 76.9 & 76.9 & 76.9 & 38.4 & 38.4 & na & na & na & 153 & 76.9 \\
\hline 8 & na & na & 150 & na & na & na & na & na & na & 150 & 75 \\
\hline 9 & 150 & 57.5 & 150 & 150 & 37.5 & 37.5 & 150 & na & 150 & na & 150 \\
\hline 10 & 144 & 72 & 144 & 36 & 72 & 36 & 144 & na & 72 & 72 & 144 \\
\hline 12 & na & na & na & na & 153 & 77.7 & 153 & na & 153 & 153 & na \\
\hline Amoxicillin & 0.49 & 0.49 & 16.1 & 4 & 16.1 & 8.1 & 4 & - & - & - & - \\
\hline Streptomycin & 10.8 & - & - & - & - & - & - & - & - & - & - \\
\hline Fluconazole & - & - & - & - & - & - & - & - & $>300$ & 90.8 & 81.6 \\
\hline Itraconazole & - & - & - & - & - & - & - & - & 17.7 & 35.4 & 35.4 \\
\hline
\end{tabular}

Abbreviations for microbes: $S$. aur $=$ S. aureus NCTC 6571. S. fae $=$ S. faecalis NCTC 775. MRSA = MRSA PHLS M1. E. clo $=$ E. coli NCTC 9001. A. nig = A. niger IM117454. A. nid = A. nidulans CABI 0160037. C. alb = C. albicans NCPF 3179 (reprinted with permission from J. Med. Chem., 2004, 47, 2133. Copyright 2004 American Chemical Society). 
group. However, when there were several alkyl groups attached to the heterocyclic ring (pyrrole), this led to a weak binding or no binding at all to the sequence AAATTATATTAT in the electrophoresis (CE) experiments. ${ }^{9}$

Khalaf et al., ${ }^{9}$ reported a large number of DNA minor groove binders bearing a variety of alkyl groups on the heterocyclic rings. Also, the pyrrole ring was replaced with a range of heterocyclic rings: such as thiazole, thiophene, imidazole and oxazole.

They also reported the biological activity (Table 1) of these compounds against a number of Gram-negative and Gram-positive bacteria as well as fungi. Here is a small selection as a representative example of these MGBs.

\section{1. MGBs Containing One or More Heterocyclic Rings Other Than Pyrrole}

\section{1. 1. MGBs Containing Isopropylthiazole}

Several heterocyclic rings were incorporated in the synthesis of the MGBs and among these were isopropylthiazole. Khalaf et al ${ }^{5,23}$ published several research papers in this field since it exhibits unique binding to the minor groove. These compounds showed very specific binding to a region of DNA which was identified by footprinting, NMR studies and CE measurements. ${ }^{9}$ This binding domain is ACTAGT and this molecule binds in a ratio of 2:1 in a head-to-tail fashion (Scheme 3).

Antony et al. ${ }^{8,9}$ have studied this molecule extensively due to its selectivity to the GC region of the oligonucleotides. This molecule was later named by the authors as "Thiazotropsin A". NMR as well as molecular modelling studies produced a vast amount of information about the behaviour of this molecule. Fig. 1-3 as well as Scheme 3 illustrate the way this molecule winds itself around the oligonucleotide [DNA duplex d(CGACTAGTCG)2] in a head-to-tail fashion. Two molecules of this compound bind side-by-side in the minor groove however, because of the bulky isopropyl moiety of the substituted thiazole ring, the two molecules are staggered relative to each other and the complex reads a total of 6 base pairs.<smiles>CC(C)c1sc(NC(=O)c2cc(NC(=O)c3cc(NC=O)cn3C)cn2C)nc1C(=O)NCCCN(C)C</smiles>

Scheme 3. Structure of Thiazotropsin A
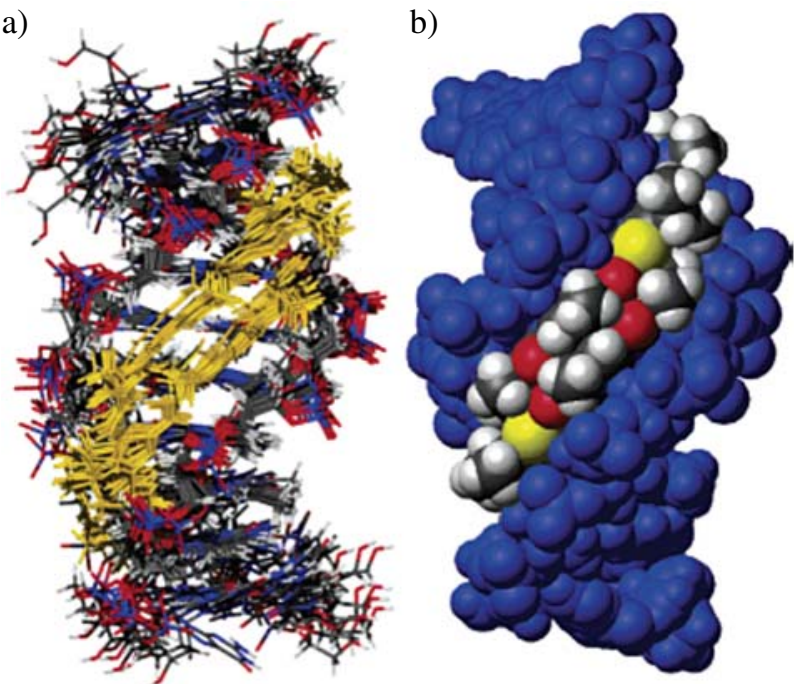

Figure 1. Representation of the solution structure of the complex between two Thiazotropsin A molecules (1 and 2) determined in aqueous solution by NMR spectroscopy. (a) Overlay of a family of 10 lowest energy structures taken from different parts of the molecular dynamics trajectory; the ligand is represented in gold. (b) $\mathrm{CPK}$ representation of the average structure looking into the minor groove: ligand atoms are coloured by atom type; all DNA atoms are shown in blue (reprinted with permission from J. Am. Chem. Soc., 2004, 126, 11338. Copyright 2004 American Chemical Society).

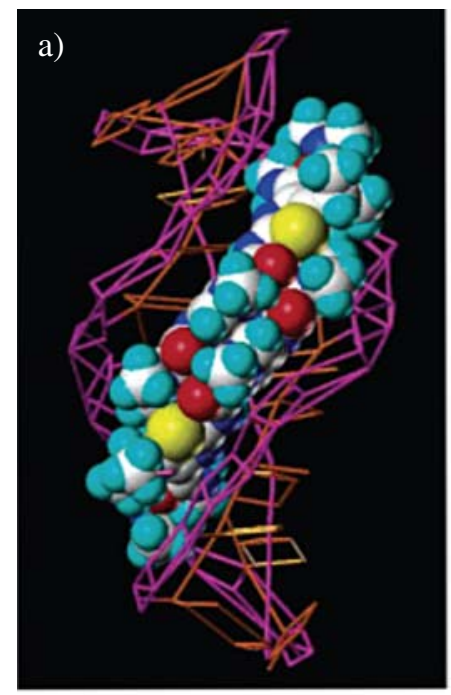

b) 3
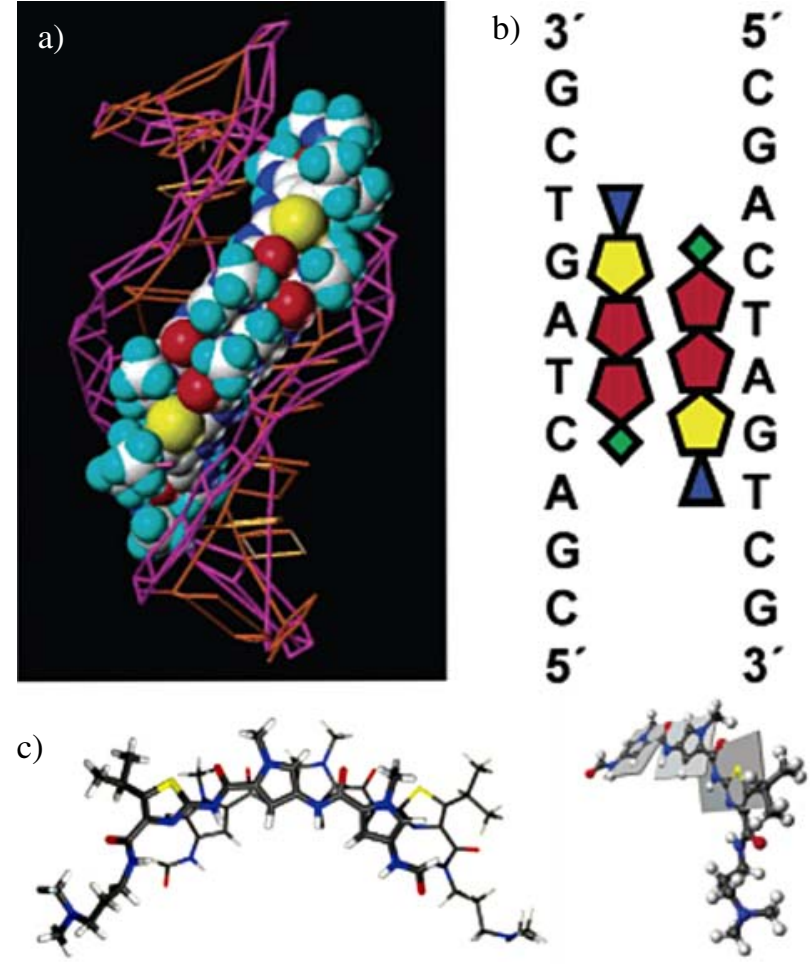

Figure 2. Cartoon and schematic representation of the complex between two thiazotropsin A molecules (1 and 2) showing the location of 1 with respect to the DNA sequence. See reference 11 for additional information (reprinted with permission from J. Am. Chem. Soc., 2004, 126, 11338. Copyright 2004 American Chemical Society). 


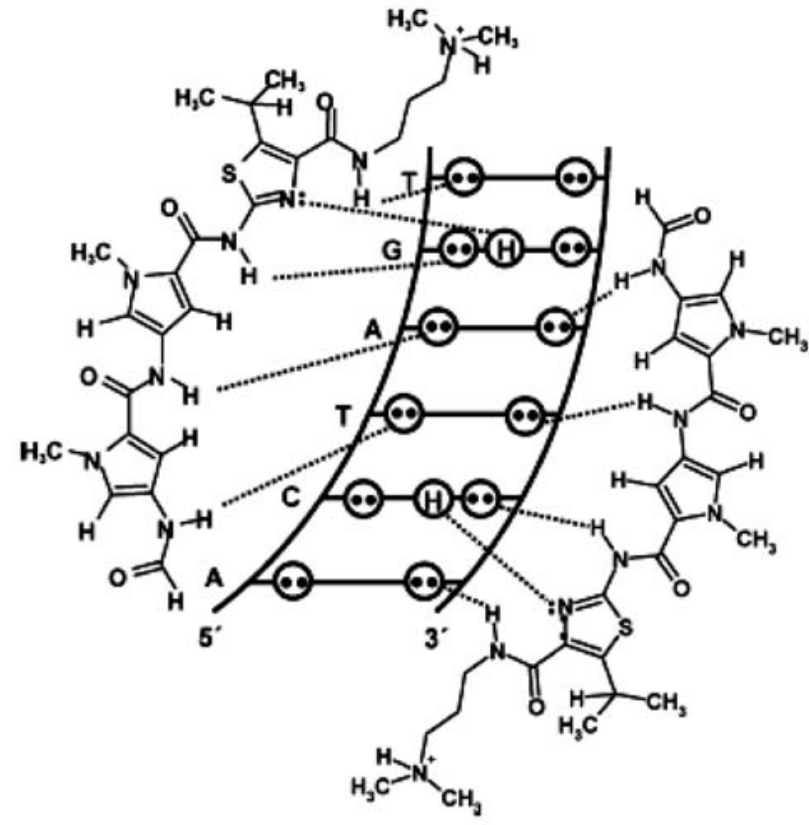

Figure 3. Expected arrangement of hydrogen bonding between 1 and the DNA duplex d(CGACTAGTCG)2, 2 (reprinted with permission from J. Am. Chem. Soc., 2004, 126, 11338. Copyright 2004 American Chemical Society).

Fig. 1-3 show that the researchers have managed to design molecules which can recognise each other and bind to a specific oligonucleotide in a side-by-side and head-totail fashion. Branched alkyl groups were introduced into the design of the minor groove binding molecules at the University of Strathclyde. Distamycin A analogues having an isopropyl moiety joined to the pyrrole ring have attracted the interest of many researchers. ${ }^{12}$ These compounds have shown higher affinity than the original Distamycin A and they showed a different pattern of binding selectivity. ${ }^{9}$ The use of thiazole instead of pyrrole is very interesting since the sulfur atom is large and should have a major effect on partitioning into biological membranes. Thiazotropsin A has both the branched alkyl side chain (isopropyl) and the thiazole moiety. This will make the adjacent part of the molecule very bulky and hydrophobic. DNA footprinting studies with thiazotropsin A using a 200 base pair DNA construct revealed only one binding site centered around the sequence 5'-ACTAGT-3 ${ }^{\prime 9}$ which had a very high affinity.

\section{1. 2. MGBs Containing Isopropylthiazole and $\mathrm{N}$-Methylimidazole}

Parkinson et al. ${ }^{17}$ have managed to determine the sequence specificity of a closely related compound to Thiazotropsin A, in which one of the $N$-methylpyrrole groups was replaced with $N$-methylimidazole; this was named Thiazotropsin B (Scheme 4a). By comparison with the Dervan rules for sequence recognition, and allowing for the staggered side-by-side binding of these compounds, the authors ${ }^{17}$ predicted that this compound should bind to the sequence $(\mathrm{A} / \mathrm{T}) \mathrm{CGCG}(\mathrm{A} / \mathrm{T})$. They have used deoxyribonuclease I and hydroxyl radical footprinting and fluorescence melting to explore the sequence specificity of this compound. Thiazotropsin A was prepared as previously described, ${ }^{4,7,12,15}$ while Thiazotropsin B was synthesized as described below (Schemes 4a, 4b).

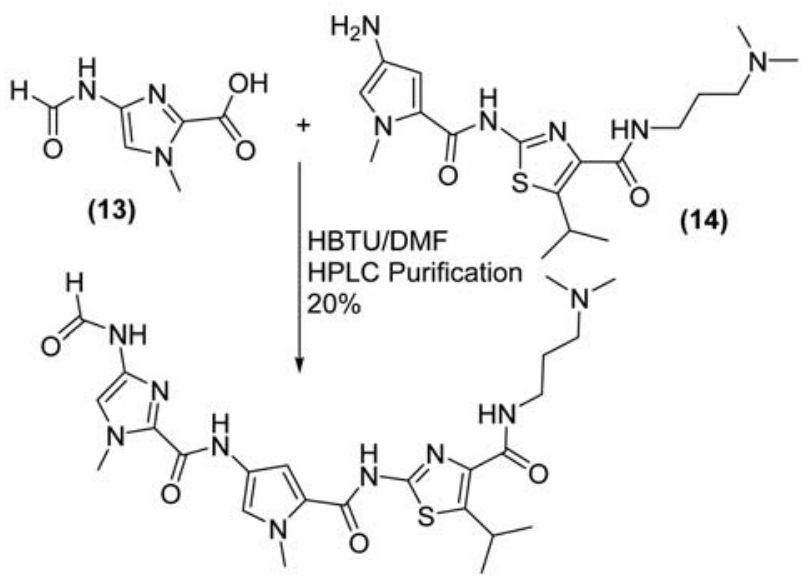

Thiazotropsin B

Scheme 4a. Synthesis of Thiazotropsin B

Fig. 4 shows the results of deoxyribonuclease I and hydroxyl radical footprinting experiments with these compounds on DNA fragments MS1 and MS2. ${ }^{25,49}$ These footprinting substrates contain all the 136 possible tetranucleotide sequences: MS1 and MS2 contain the same sequence, which was cloned in opposite orientations, allowing good resolution of target sites at both ends of the fragment. The authors expected that Thiazotropsin B would possess a binding site that is longer than four base pairs [probably (A/T)CGCG(A/T)]. The first two panels of Fig. 4 show the deoxyribonuclease I cleavage patterns, in which three footprints are evident on each strand, which are indicated alongside the sequence in Fig. 4.

The concentrations required to generate these footprints (10 $\mu \mathrm{M}$ and above) are higher than those previously reported for Thiazotropsin A $(1 \mu \mathrm{M})$. The footprint at site 1 persists to lower concentrations $(10 \mu \mathrm{M})$ than the other two sites $(25 \mu \mathrm{M})$. This site contains the sequence GCGCGA, which differs from the predicted target (A/T)CGCG(A/T), at only the first base pair. They have previously shown that Thiazotropsin A binds to the sequence ACTAGT and it is clear that Thiazotropsin B binds at a different location. This is emphasized in the third panel of Fig. 4 which directly compares the deoxyribonuclease I footprinting patterns of these two ligands. The footprint for Thiazotropsin A (labelled ' $A$ ') is not affected by Thiazotropsin B and the three Thiazotropsin B sites are not affected by Thiazotropsin A. It is clear that these two ligands have very different sequence 


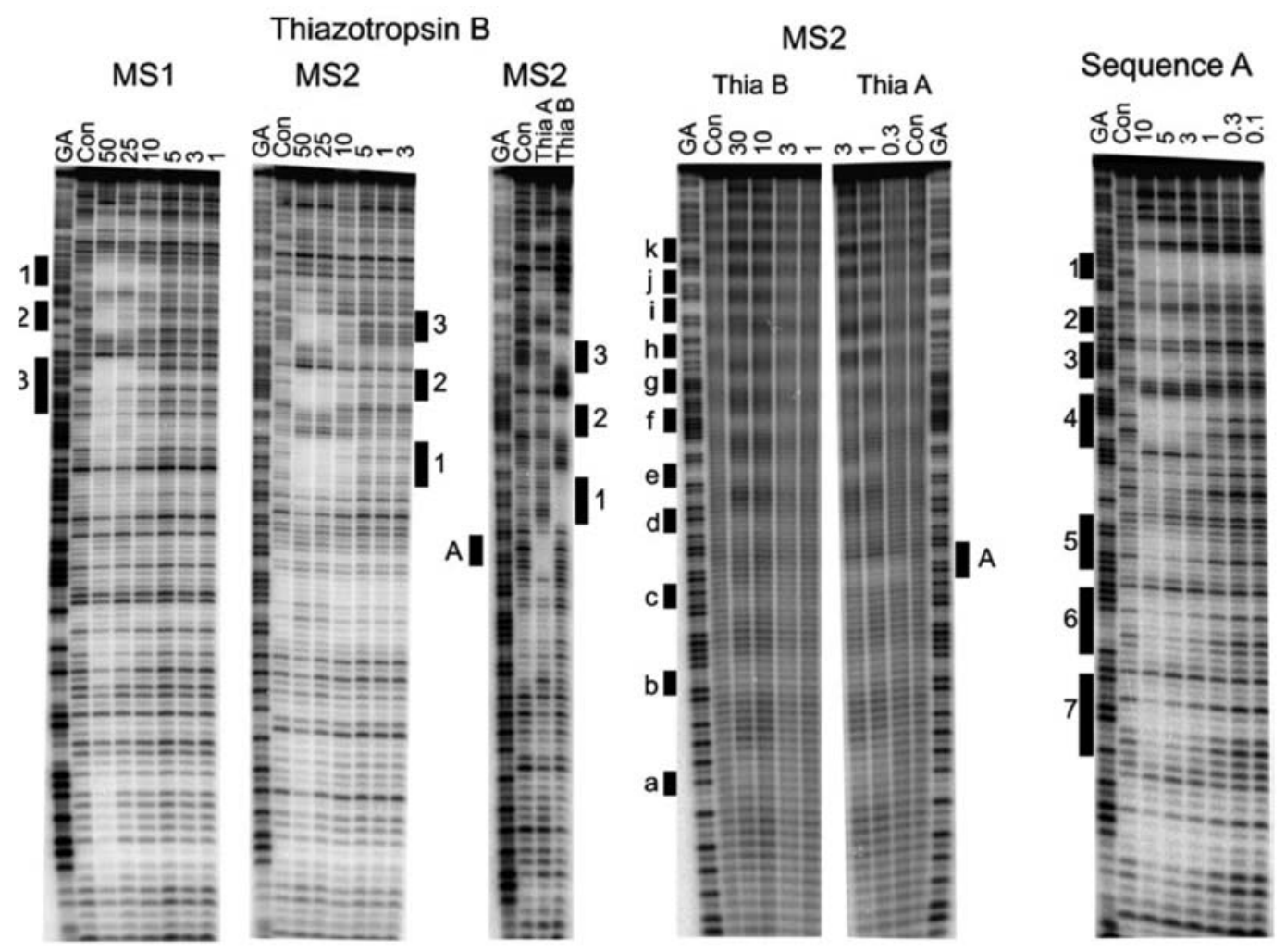

Figure 4. The first two panels show deoxyribonuclease I footprints for Thiazotropsin B on MS1 (top strand, Figure 4a) and MS2 (bottom strand, Figure 4a). The third panel compares the deoxyribonuclease I footprints for Thiazotropsin A $(10 \mu \mathrm{M})$ and Thiazotropsin B $(50 \mu \mathrm{M})$ on MS2. 'A' indicates the location of the binding site for Thiazotropsin A. The fourth and fifth panels show hydroxyl radical cleavage patterns for these ligands on the MS2 fragment. The final panel shows deoxyribonuclease I cleavage patterns of Sequence A in the presence of Thiazotropsin B. Ligand concentrations $(\mu \mathrm{M})$ are shown at the top of each gel lane. GA corresponds to marker lanes specific for purines, while 'Con' is cleavage in the absence of added ligand. The filled boxes show the location of the best binding sites (reproduced from the reference 15 with permission from Bioorg. Med. Chem. Lett., license number: 3905281229232).<smiles>[R]C(=O)Nc1[X]c(C(=O)Nc2cc(C(=O)Nc3nc(C(=O)NCCCN(C)C)c(C(C)C)s3)n(C)c2)n(C)c1</smiles>

\begin{tabular}{ll}
\hline Name & Sequence \\
\hline ACGCGT & 5'-F-CCGACGCGTGC-3' \\
& 3'-Q-GGCTGCGCACG-5' \\
ACTAGT & 5'-F-CCGACTAGTGC-3' \\
& 3'-Q-GGCTGATCACG-5' \\
\hline
\end{tabular}

Scheme 4b. Structures of Thiazotropsin A $(X=C, R=H)$ and Thiazotropsin $\mathrm{B}\left(\mathrm{X}=\mathrm{N}, \mathrm{R}=\mathrm{CH}_{3}\right)$ and their binding properties. Fluorescently labelled sequences used in the thermal melting experiments were: $\mathrm{F}=$ fluorescein and $\mathrm{Q}=$ methyl red (reproduced from the reference 15 with permission from Bioorg. Med. Chem. Lett., license number: 3905281229232). binding requirements, even though they only differ by a single atom. Site 2 contains the sequence TCCCGT, which also differs from the predicted target at 1 base pair in the third position. Site 3, which contains the sequence TAGCAA, is less closely related and differs from the predicted sequence in the second and fourth positions. ${ }^{12,15}$

\section{MGBs with Anti-parasitic Activity}

Minor groove binders have been used against trypanosomiasis since the 1930s. This is exemplified by the use of bis-amidines, pentamidine and diminazene. These were used as the first-line treatments for Human African Trypanosomiasis (HAT) and Animal African Trypanosomiasis (AAT), consecutively. ${ }^{47} \mathrm{~A}$ large number of similar compounds have been synthesised and evaluated against trypanosomiasis and, moreover, many have been found useful against protozoan infections, including leishmaniasis and malaria. ${ }^{48}$

Trypanosoma brucei is a species of parasitic protozoan. It causes African trypanosomiasis, which is also known as sleeping sickness in humans and nagana in ani- 
mals. ${ }^{35}$ T. brucei can be divided into three subspecies: $T$. $b$. brucei, T. $b$. gambiense and T. b. rhodesiense. The latter two are parasites of humans, while the first is that of animals. Only rarely can the $T$. b. brucei infect a human. $T$. b. brucei is transmitted between mammal hosts by an insect vector which belongs to the species of tsetse fly. The transmission occurs by biting during the insect's blood meal. The parasites undergo several morphological changes as they move between insect and mammal over the course of their life cycle. T. brucei is one of only a few pathogens that have the capability of crossing the blood brain barrier. ${ }^{36}$ New drug therapies are urgently needed to be developed, as existing treatments can prove fatal to the patient. ${ }^{37,38}$

This parasite was first discovered in 1894 by Sir David Bruce, after whom the scientific name was given in 1899. ${ }^{39,40}$

Lang and others have designed MGBs that interfered with the DNA of certain parasites. This was demonstrated in a number of publications. ${ }^{26,29,30}$ These were thiazole-containing compounds, activity was found against Trypanosoma brucei (see Tables 2 and 3 ).

Of particular interest is a molecule which does not contain a typical basic flexible tail group found in MGBs, but instead has an unprotected carboxylic acid group at

Table 2. Selected examples of anti-trypanosomal activity of heterocyclic oligoamide dimers (for more examples see reference 26)

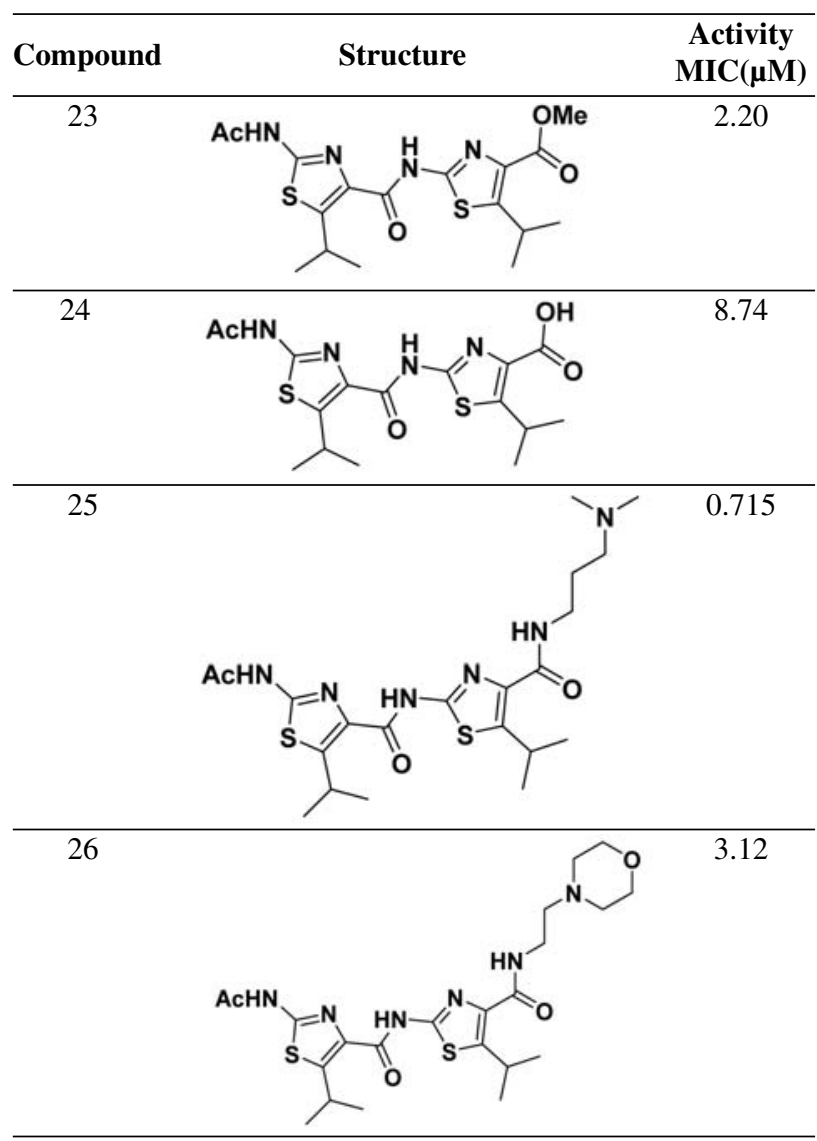

Table 3. Selected examples of anti-trypanosomal activity of heterocyclic oligoamide trimers (for more examples see reference 26)

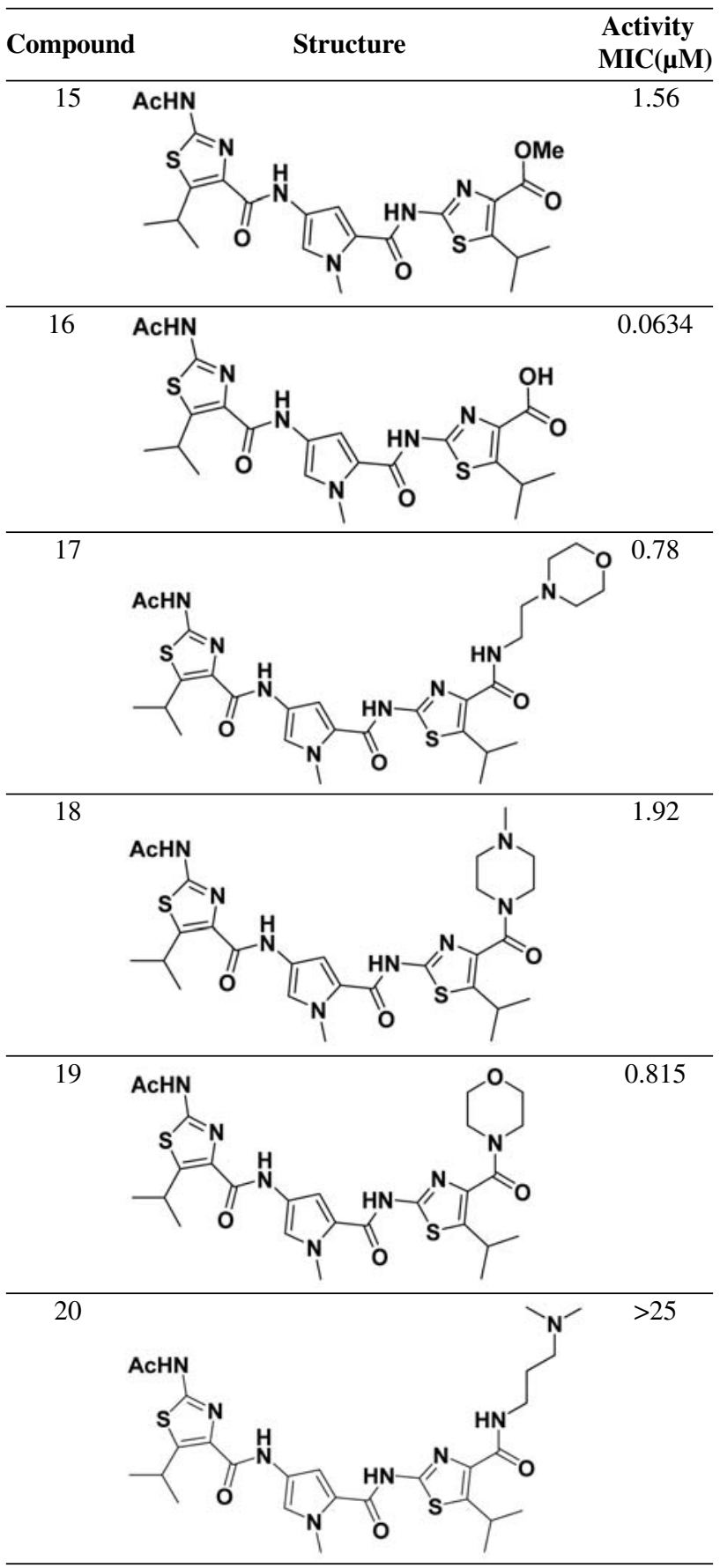

that position (compound 16 which has activity of $63 \mathrm{nM}$ against $T$. brucei). These compounds showed consistent activity against $T$. brucei. 2-Amino-5-alkylthiazole-4-carboxylic acid derivatives (Schemes 5 and 6) were found to be common components of the active compounds. It was of interest, therefore, to investigate the structure-activity relationship in this series in particular by reducing the size of the compounds from the original tetracyclic minor groo- 
ve binders so that these compounds would be more drug-like. Trypanosomes have characteristic structures, known as kinetoplasts, in which circular DNA is packaged densely within a large mitochondrion. ${ }^{27,28}$ Assays for activity against $T$. brucei were carried out using established methods at the laboratories in Strathclyde and Glasgow Universities. ${ }^{29}$ Compound 20 is typical of an antibacterial and antifungal minor groove binder with an MIC vs. S. Aureus $4.3 \mu \mathrm{M}$, vs. A. niger $4.3 \mu \mathrm{M}$. However, this compound was found to be inactive against $T$. brucei. The C-terminal compound 16 showed the highest activity of $63 \mathrm{nM}$. This was the highest activity found in any of the compounds investi- gated by the authors. ${ }^{24}$ The corresponding ester 15 and the piperazinyl amide 18 were 20-30-fold weaker in activity; and the morpholine amides 17 and 19 were 3 -10-fold weaker in activity, although they have the same basic structures. Tables 2 and 3 show the results for the dimers and these appeared to have weaker activity than the trimers. The greatest activity was found in compounds containing the dimethylaminopropyl C-terminal amide (Schemes 5 and 6). ${ }^{27}$ The dimethylaminopropyl group is common in antibacterial minor groove binders. ${ }^{9,16,30}$ The ionized C-terminal group which is protonated at physiological $\mathrm{pH}$, seems to be a crucial element in the activity of these compounds.

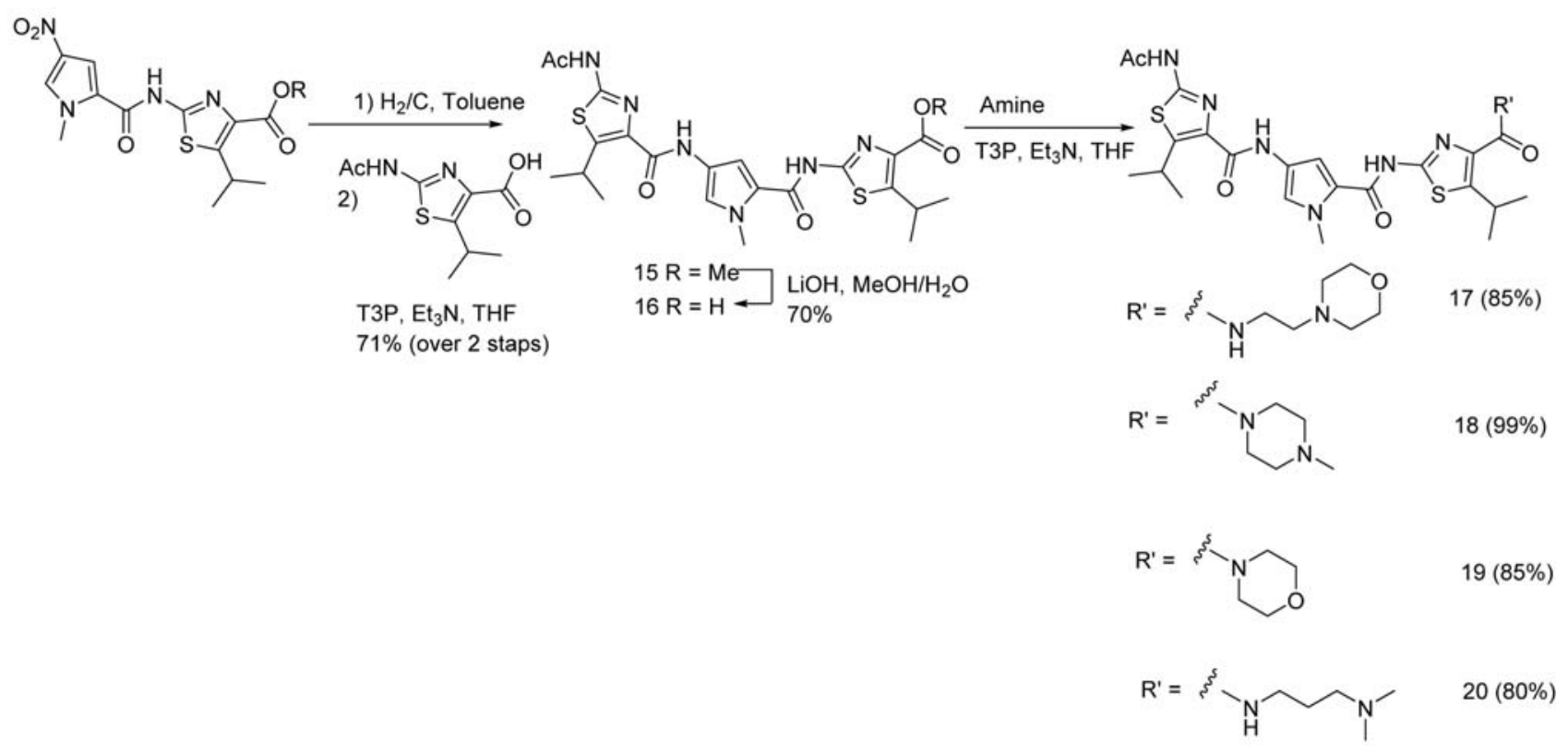

Scheme 5. Synthesis of heterocyclic oligoamide trimers

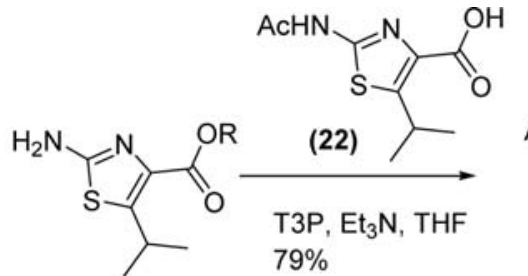

(21)<smiles>[R2]OC(=O)c1nc(NC(=O)c2nc(NC=[W])sc2C(C)C)sc1C(C)C</smiles>

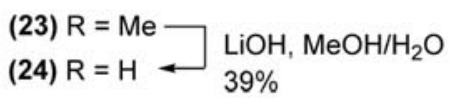<smiles>[Z10]Nc1nc(C(=O)Nc2nc(C([R])=O)c(C(C)C)s2)c(C(C)C)s1</smiles><smiles>[R]=C=CNCCCNCCN1CCOCC1</smiles>

(25) $(80 \%)$ 
This could mean that these compounds are disrupting the kinetoplast, which is a well known lethal event for trypanosomes. ${ }^{31}$ Compound 16 (carboxylic acid) trimer appeared to have an exceptionally high activity in terms of DNA binding. Also, the ionic group may be crucial in transport of the active compound to its target, and this is an important role in anti-trypanosomal compounds. ${ }^{32}$ It is obvious that all the elements in structure 16 are required because the dimer carboxylic acid 24 is significantly active. The authors ${ }^{26}$ presented in their research a new class of heterocyclic oligoamide carboxylic acid exemplified by 16 as a new type of potential anti-trypanosomal compound. If this compound proved to be a DNA minor groove binder, this would mean that it has the same mode of action as the well-established anti-trypanosomal diamidines, ${ }^{32}$ which have been studied extensively.

At Strathclyde we have developed a large number of MGBs which are structurally similar to the natural product Distamycin. ${ }^{46}$ This compound was built from $N$ methylpyrrole amino acid amides and has an amidine end group (Scheme 1). Also, we modified a number of the fragments of the original structure. We have introduced<smiles>CNC(=O)c1cc(NC(=N)c2cccc(OC)c2)cn1C</smiles>

Amidine linked head group<smiles></smiles>

Example: MGB with three heterocycles<smiles>CCNC(=O)c1cc(NC(=O)c2cccc(OC)c2)cn1C</smiles>

Amide linked head group<smiles>CNC(=O)c1cc(/C=C/c2cccc(OC)c2)cn1C</smiles>

Alkene linked head group<smiles>CN(C)CCCNC(=O)c1cc(NC(=O)c2cc(NC(=O)c3cc4ccccc4cn3)cn2C)cn1C</smiles>

Example: MGB with two heterocycles

Figure 5. Exemplars of the types of MGBs investigated in reference 46

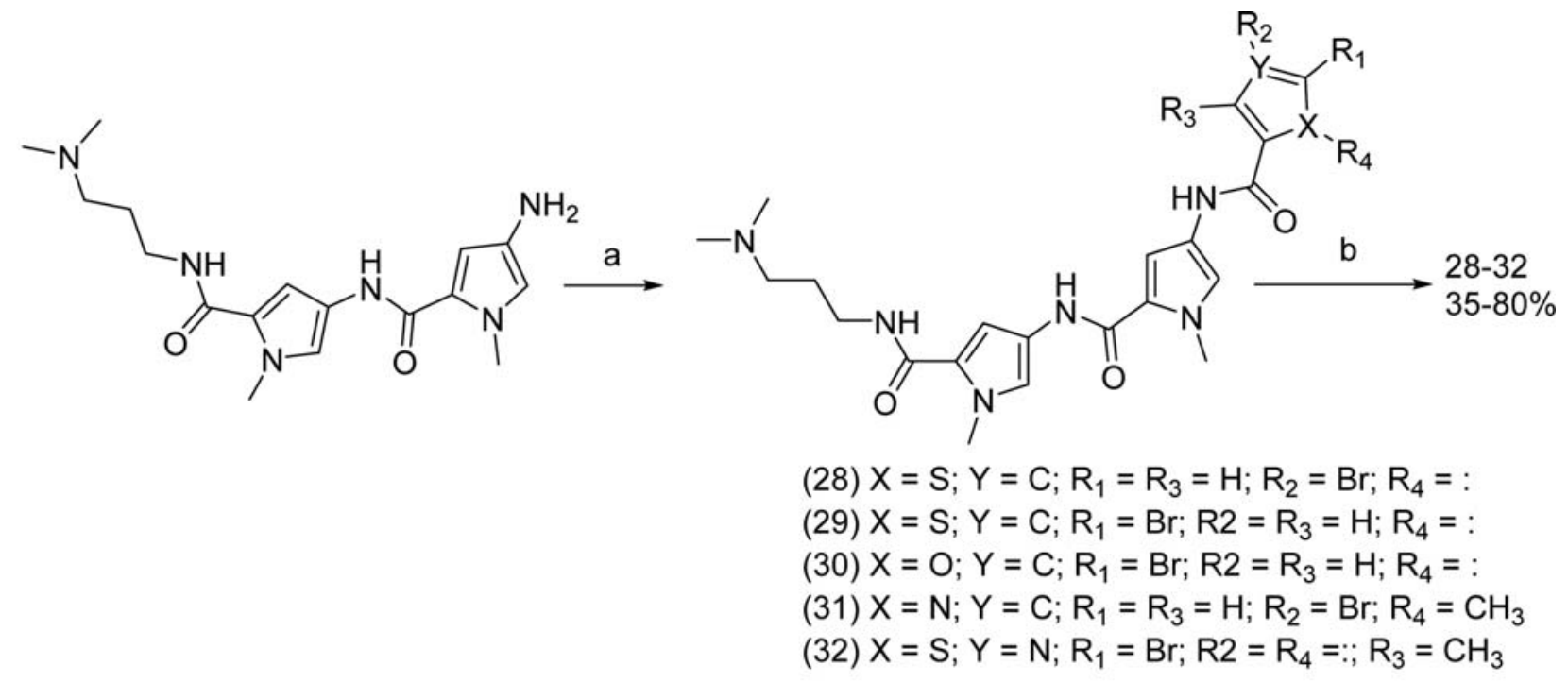

Scheme 7. General synthetic scheme for the synthesis of the biaryl containing MGBs (a) HOBt, DIC, $16 \mathrm{~h}$, rt; (b) $\mathrm{Pd}\left(\mathrm{PPh}_{3}\right)_{4}, \mathrm{~K}_{2} \mathrm{CO}_{3}$, microwave (for more details see reference 33). 
less basic functional groups to replace the amidine at the C-terminus. Moreover, larger alkyl side chains have substituted the methyl groups in the pyrrole rings. And, thiazole rings have been introduced into the MGB. Also, aromatic rings have replaced the formyl group from Distamycin $\mathrm{A}$ and the $\mathrm{N}$-terminal amide has been replaced by its isosteric alkene (Fig. 5). ${ }^{9,16}$

In summary the authors have demonstrated that their MGBs possess activity against $T$. b. brucei. Furthermore, five compounds have been identified as leads for further investigation, each with IC50 values lower than $40 \mathrm{nM}$.

\section{MGBs for the Treatment of Tuberculosis}

Brucoli and co-workers ${ }^{33}$ evaluated several of these DNA-minor groove binding agents (Schemes 7 and 9).<smiles>[X][Y]1cc(C(=O)Nc2cc(C(=O)Nc3cc(C(=O)NCCCN(C)C)n(C)c3)n(C)c2)cc([X])c1C=C</smiles>

Scheme 8. Schematic representation of the synthesis of the final compounds (for more examples see reference 33)

Table 4: Representative examples of the biological activity screening results ${ }^{33}$

\begin{tabular}{|c|c|c|c|c|}
\hline Structure & $\begin{array}{c}\text { M. tuberculosis } \\
\mathbf{H}_{37} \mathbf{R v}^{\mathbf{a}}\end{array}$ & $\begin{array}{c}\text { M. bovis } \\
\text { BCG }^{\mathbf{a}}\end{array}$ & $\begin{array}{l}\text { RAW } \\
264.7^{\text {b }}\end{array}$ & $\mathbf{S I}^{\mathbf{c}}$ \\
\hline Distamycin & 31.25 & 1.95 & 62.5 & 2 \\
\hline & 62.5 & 125 & 62.5 & 1 \\
\hline & 31.25 & 125 & 250 & 8 \\
\hline & 250 & 125 & 62.5 & 0.25 \\
\hline & 15.62 & 31.25 & 62.5 & 4 \\
\hline & 62.5 & 7.8 & 62.5 & 1 \\
\hline Isoniazid & 0.05 & 0.05 & 3000 & 60,000 \\
\hline Rifampin & 0.05 & 0.05 & 700 & 14,000 \\
\hline
\end{tabular}

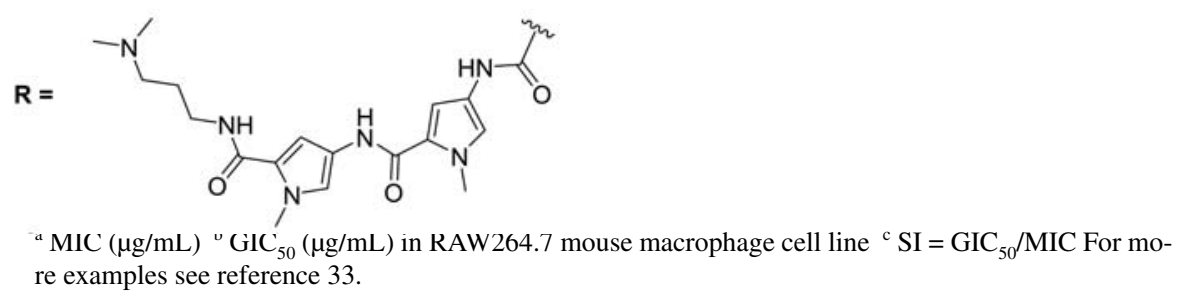


Tuberculosis is a well known disease and statistics show that around nine million people contracted it in $2013 .{ }^{34}$ To make matters worse, the occurrence of extensively-drug resistant TB (XDR-TB) strains requires prompt therapeutic intervention and, therefore, new molecules with novel mechanisms of action are urgently needed. Sequence-selective DNA minor groove-binding agents can be exploited to target specific promoter regions of M. tuberculosis DNA and disrupt transcription factors; this would cause bacterial cell death and overcome drug resistance-related issues. To examine this idea, Brucoli and co-workers ${ }^{33}$ synthesised and evaluated the anti-mycobacterial activity of a number of Distamycin A analogues (Table 4) in which the constituent $N$-terminal pyrrole-formamido moiety of Distamycin was substituted with biaryl units. They have introduced the biaryl-motifs at the $N$-terminal position in order to improve the DNA sequence-selectivity of Distamycin, and overcome the $\mathrm{H}$-bond recognition issues relative to polyamides containing several $N$-methylpyrrole rings, which are thought to be over-curved in comparison to the DNA helix. ${ }^{41}$ These compounds were prepared as illustrated in Schemes 7 and 8 and in Table 4.

\section{MGBs for the Treatment of Lung Cancer}

We at the University of Strathclyde have also embarked upon the synthesis and evaluation of a range of minor groove binders designed for the treatment of lung cancer.
There are a range of compounds prepared in our laboratories based on the principle that these compounds would inhibit the growth of lung cancer cells. Distamycin does not possess significant cytotoxicity; however, other classes of minor groove binders have shown significant possibility as anti-cancer agents, in particular those which are derived from the distamycin structure (Scheme 9). ${ }^{45}$

\section{Anti-Malarial Minor Groove Binders}

Recently Scott et al. $^{51}$ published their research work in the field of combating malaria by using minor groove binders. There are worldwide efforts in the control and prevention of malaria. From 2000 to 2015 there was a dramatic reduction both in the incidence $(37 \%)$ and mortality rate $(60 \%)$ due to malaria infections; however, the threat of parasite resistance is still frightening and could undermine these achievements. ${ }^{52}$ Three of the five Plasmodium species which are known to infect humans ( $P$. falciparum, $P$. vivax and $P$. malariae) have all demonstrated resistance to commonly used antimalarial drugs. Due to the resistance to Artemisinin monotherapy and also to the combination therapy (ACT) reported as a delayed clearance of infection with standard dosing regimens, there is a need for new antimalarial compounds. Those with alternative modes of action are of the highest value as cross-resistance generated to all compounds within the same chemical class or mode of action is a common phenomenon. In spite of how the work to-

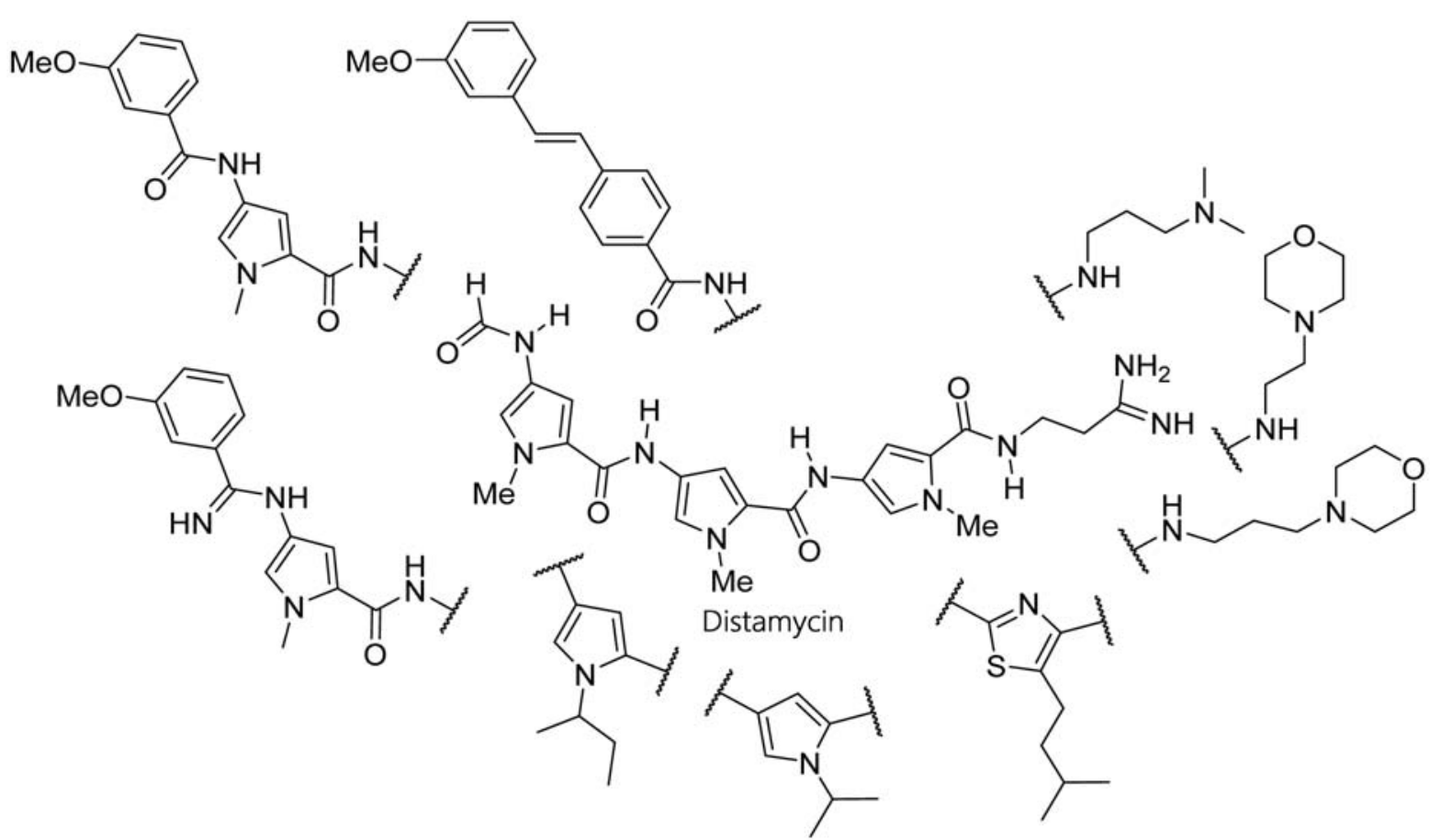

Scheme 9. Representative examples of the structural variations in the MGB set investigated as potential candidates for treatment of lung cancer. 
wards this goal is progressing, several heterocyclic compounds such as DDD107498 (Fig. 6), there is still the need to have a number of compounds in the pipeline as potential novel therapeutics, should resistance emerge. A number of screening campaigns have identified new drug candidates which appear to be clustering to a small number of protein targets, for example PfATP4, PI4K and PfDHODH. The identification of new compounds with alternative targets or modes of action is an obvious route to take with the intention of minimizing the threat of cross resistance. ${ }^{53-57}$

The data shown in Table 5 illustrate the structures of both significantly active and inactive compounds. No sig-<smiles>O=C(NCCN1CCCC1)c1cc(-c2ccc(CN3CCOCC3)cc2)nc2ccc(F)cc12</smiles>

DDD107498

Figure 6. Structure of DDD107498

Table 5. Representative examples of S-MGB Structures: Anti-malarial minor groove binders

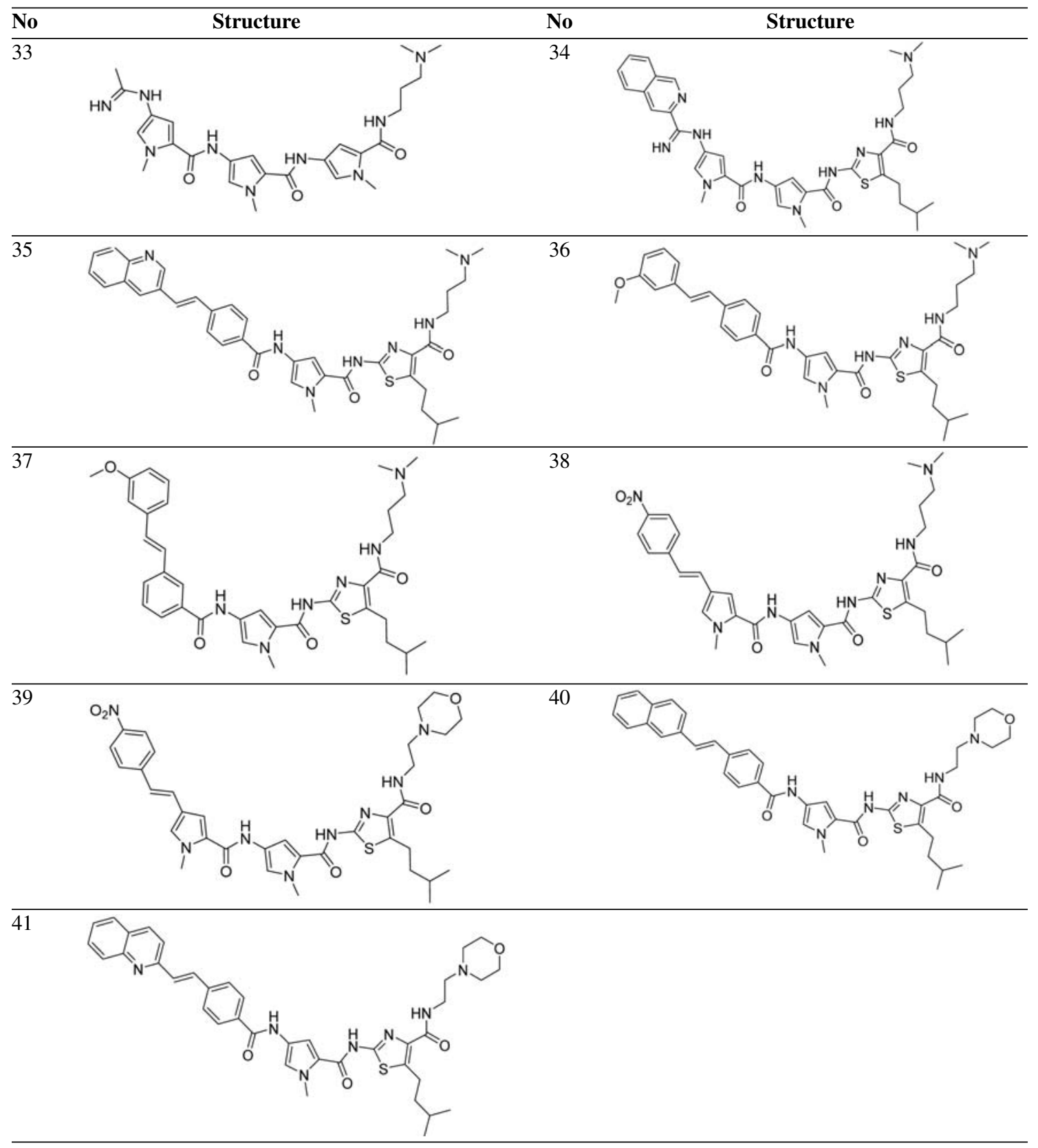


nificant activity was observed in compounds without an aromatic head group. ${ }^{42,43}$ The activity and selectivity were found almost entirely within the alkene-linked subset of compounds; the amidine-linked compounds were all at best weakly active and only one amide-linked compound had significant activity. ${ }^{58}$ Interestingly, this compound contains a C-alkylthiazole with an isopropyl chain, a structural feature that seems to promote antimalarial activity. Overall, five of the most active compounds, all alkene linked, contained a C-alkylthiazole (compounds 33-41). Even in the weakly active amidine series, the Calkylthiazole noticeably increased the activity. Importantly, approximately equal activity was observed between the resistant and sensitive strains.

\section{Phase I Clinical Trial of Our MGB}

Hundreds of MGBs were synthesised in our laboratory here at the University of Strathclyde. These were tested in a variety of ways for their biological activities. After several years of research, one of the MGBs was found to be very effective against Clostridium difficile. This drug candidate has been patented and licensed to a pharmaceutical company in Scotland. The synthesis of this drug MGB-BP-3, as can be seen in Scheme 10, consists of joining two parts: head group which is stilbenelike moiety and the second part of the molecule consisting of two $\mathrm{N}$-methylpyrroles attached to an aminoethyl morpholine. ${ }^{16,24 a, 43,44}$
MGB-BP-3 is an antibacterial drug which has a broad activity against a number of very important multi drug resistant Gram-positive pathogens. MGB Biopharma Ltd. has managed to develop an oral formulation of MGB-BP-3 for the treatment of $C$. difficile infections which has passed Phase One clinical trials. There are many drugs being used for the treatment of bacterial infections, however, these have been used for several decades and because of the rise in resistant strains of bacteria, therefore, the usefulness of many of these drugs is diminishing. MGB-BP-3 was first synthesised according to Scheme 10 using a convergent method by which two parts of the molecule were prepared separately and then coupled at the last step.

The crucial point of the MGB-BP-3 class of antibacterial compounds is their selectivity for Gram-positive bacteria and they have no activity against mammalian cells. This became obvious from the data obtained from another compound AIK-20/25/1. This compound is almost as active as MGB-BP-3. Fig. 7 shows the effect on cellular viability for this compound comparing a mammalian cell line (HS27 murine fibroblast) with Staphylococcus aureus. It can be seen from the Fig. 8 that the difference is huge. There is no evidence of toxicity to be found with the HS27 cells but catastrophic death was found for the bacteria. The catastrophic bactericidal death is believed to be a result of the minor groove binders interfering with a number of biochemical pathways that together lead to this catastrophic death. ${ }^{42}$
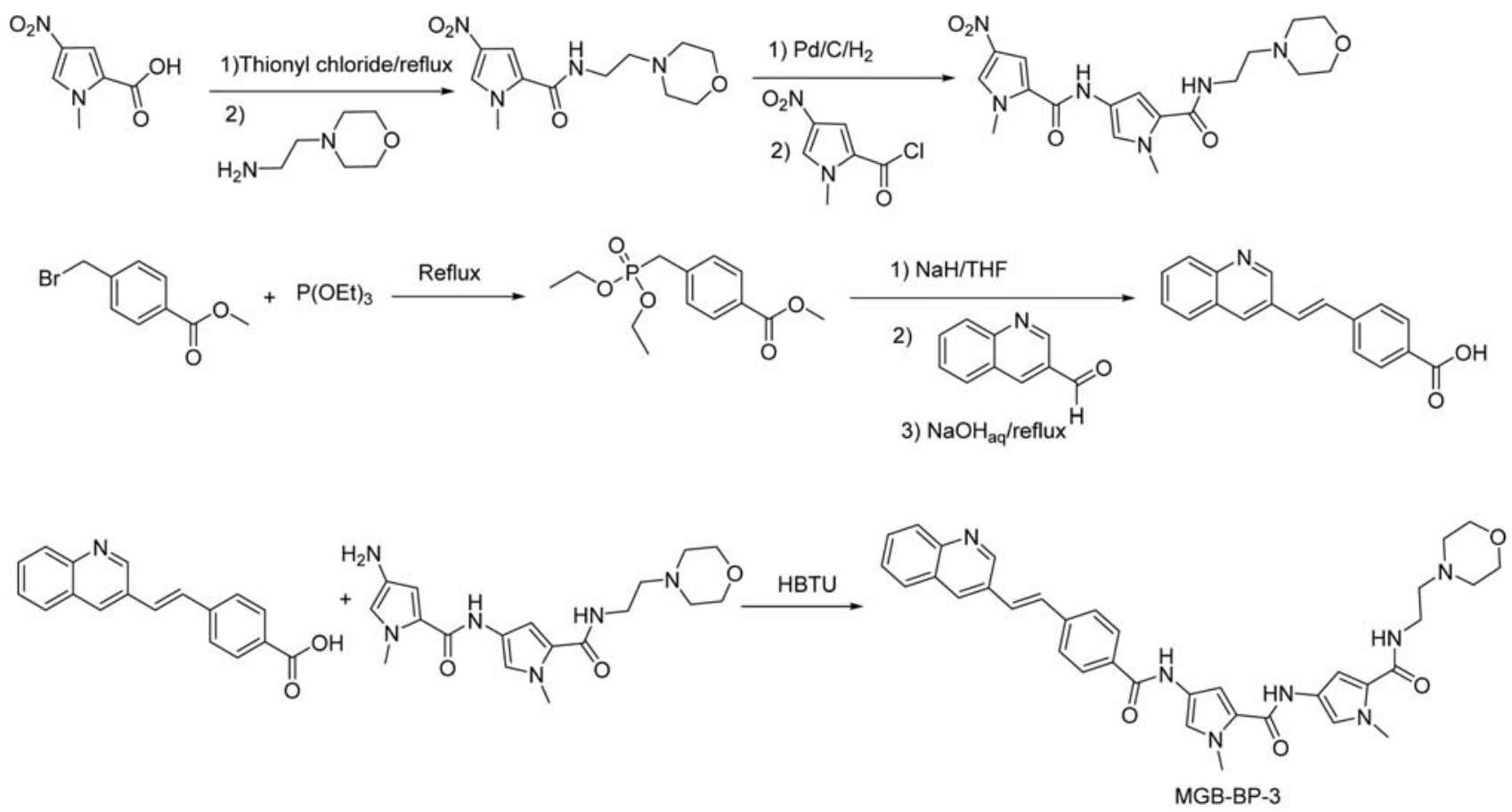

Scheme 10. Schematic representation for the synthesis of MGB-BP-3 


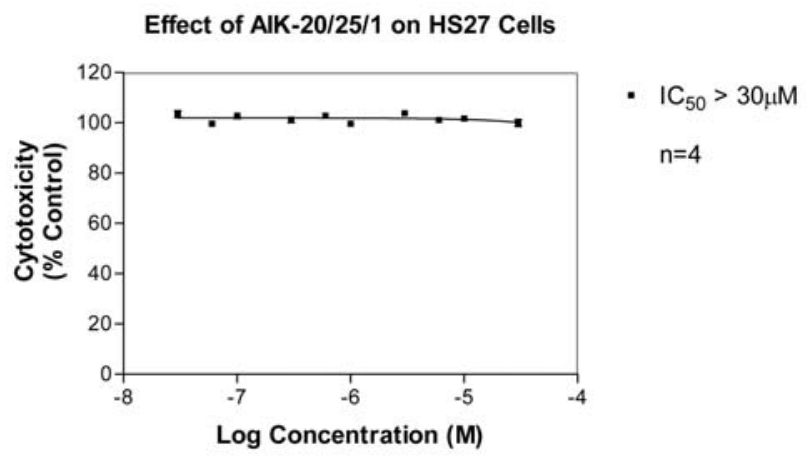

\section{The Effect of AlK-20/25/1 in the Antimicrobial Assay Against S.aureus 07/02/07}
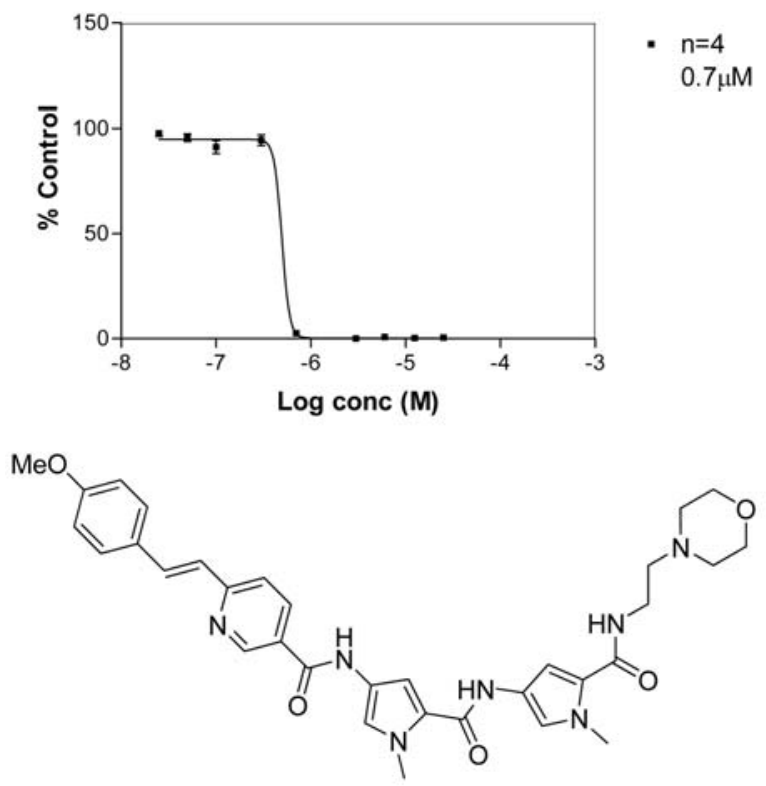

Fig. 7. Selectivity for Gram-positive bacteria shown by AIK20/25/1 (reproduced from Chem. Biol. Interface, reference 42). This is the original figure from our laboratories at Strathclyde.

\section{Conclusion}

In this review article we have attempted to highlight the importance of antibiotic resistant bacteria and the crucial steps taken to tackle this issue which is affecting a vast number of people. The subject also deals with combating neglected third world diseases such as sleeping sickness. The natural product Distamycin has been modified in many ways. The tail group was changed by replacing the amidine moiety with a variety of tertiary amines; also, the methyl pyrrole(s) were replaced with a variety of either longer alkyl (branched alkyl) groups or with a different heterocyclic ring(s). The head group was replaced with a variety of heterocyclic, aromatic or stilbene-like moieties. The physical chemical behaviour as well as the molecular modelling of some of these DNA binding compounds was studied extensively. A variety of biological assays were performed in our laboratories and those of others, on a vast number of these DNA minor groove binders. Some of these results are tabulated herein. One compound (MGB-BP-3) which was initially synthesised in our laboratories and was subsequently developed further by a small pharmaceutical Scottish company (MGB Biopharma) was selected for the treatment of a gram positive bacteria Clostridium difficile infections. This candidate drug has passed phase 1 clinical trial and has been approved for phase 2 clinical trials.

\section{Acknowledgement}

The authors would like to thank the following people for their highly appreciated help and support: Professor Colin J. Suckling, Dr Fraser J. Scott, Gavin Bain, Craig Irvin and Patricia Keating. Our gratitude also extends to Mrs Carol Khalaf (B.Sc., Post Grad. Cert.) for proof-reading this article. The hard work of all our colleagues past and present is very much appreciated.

\section{References}

1. A. R. Kennedy, A. I. Khalaf, A. R. Pitt, M. Scobie, C. J. Suckling, J. Urwin, R. D. Waigh, S. C. Young, Acta Crystallogr., Sect. C: Struct. Chem., 1999, C55 (7),ii IUC9900072. http://dx.doi.org/10.1107/S0108270199099199

2. A. I. Khalaf, A. R. Pitt, C. J. Suckling, M. Scobie, J. Urwin, R. D. Waigh, R. V. Fishleigh, S. C. Young, K. R. Fox, J. Chem. Research (S), 2000, 264-265; J. Chem. Research (M), 2000, 751-770. http://dx.doi.org/10.3184/030823400103167444

3. V. R. Fishleigh, K. R. Fox, A. I. Khalaf, A. R. Pitt, M. Scobie, C. J. Suckling, J. Urwin, R. D. Waigh, C. S. Young, J. Med. Chem. 2000, 43, 3257-3266. http://dx.doi.org/10.1021/jm990620e

4. A. I. Khalaf, A. R. Pitt, C. J. Suckling, M. Scobie, J. Urwin, R. D. Waigh, R. V. Fishleigh, S. C. Young, K. R. Fox, Tetrahedron, 2000, 56, 5225-5239. http://dx.doi.org/ 10.1016/S0040-4020(00)00432-4

5. A. R. Kennedy, A. I. Khalaf, C. J. Suckling, R. D. Waigh, Acta Crystallogr., Sect. E: Crystallogr. Commun., 2000, 57, o832-o833.

http://dx.doi.org/10.1107/S1600536801013058

6. A. R. Kennedy, A. I. Khalaf, C. J. Suckling, R. D. Waigh, Acta Crystallogr., Sect. E: Crystallogr. Commun., 2003, 59, o1410-o1412.

http://dx.doi.org/10.1107/S1600536803018828

7. A. I. Khalaf, J. A. Parkinson, C. J. Suckling, N. G. Anthony, J. J. Helsebeux, S. P. Mackay, R. D. Waigh, K. R. Fox, Drug. Future, 2004, 29 (suppl. A), 159.

8. N. G. Antony, K. R. Fox, B. Johnston, A. I. Khalaf, S. P. Mackay, I. S. McGroary, J. A. Parkinson, G. G. Skellern, C. J. Suckling, R. D. Waigh, Bioorg. Med. Chem. Lett. 2004, 14, 1353-1356. 
http://dx.doi.org/10.1016/j.bmcl.2003.11.068

9. A. I. Khalaf, A. J. Drummond, B. Pringle, I. McGroarty, G. G. Skellern, R. D. Waigh, C. J. Suckling, J. Med. Chem. 2004, 47, 2133-2156. http://dx.doi.org/10.1021/jm031089x

10. A. I. Khalaf, A. H. Ebrahimabadi, A. J. Drummond, N. G. Anthony, S. P. Mackay, C. J. Suckling, R. D. Waigh, Org. Biomol. Chem. 2004, 2, 3119-3127. http://dx.doi.org/10.1039/B408386P

11. N. G. Antony, A. I. Khalaf, S. P. Mackay, J. A. Parkinson, C. J. Suckling, R. D. Waigh, J. Am. Chem. Soc. 2004, 126, 11338-11349. http://dx.doi.org/10.1021/ja030658n

12. P. L. James, E. E. Merkina, A. I. Khalaf, C. J. Suckling, R. D. Waigh, T. Brown, K. R. Fox, Nucleic Acids Res., 2004, 32, 3410-3417. http://dx.doi.org/10.1093/nar/gkh666

13. A. R. Kennedy, A. I. Khalaf, C. J. Suckling, R. D. Waigh, Acta Acta Crystallogr., Sect. E: Crystallogr. Commun., 2004, 60, o1188-o1190. http://dx.doi.org/10.1107/S1600536804013984

14. A. R. Kennedy, A. I. Khalaf, C. J. Suckling, R. D. Waigh, Acta Acta Crystallogr., Sect. E: Crystallogr. Commun., 2004, 60, o1510-o1512. http://dx.d oi.org/10.1107/S1600536804019282

15. A. J. Hampshire, H. Khairallah, A. I. Khalaf, A. H. Ebrahimabadi, R. D. Waigh, C. J. Suckling, T. Brown, K. R. Fox, Bioorg. Med. Chem. Lett. 2006, 16, 3469-3474. http://dx.doi.org/10.1016/j.bmcl.2006.04.007

16. N. Anthony, D. Breen, J. Clarke, G. Donoghue, A. Drummond, E. Ellis, C. Gemmell, J. J. Helesbeux, I. Hunter, A. I. Khalaf, S. Mackay, J. Parkinson, C. J. Suckling, R. D. Waigh, J. Med. Chem. 2007, 50, 6116-6125. http://dx.doi.org/10.1021/jm070831g

17. J. A. Parkinson, A. I. Khalaf, N. G. Anthony, S. P. Mackay, C. J. Suckling, R. D. Waigh, Helv. Chim. Acta, 2009, 92, 795-822. http://dx.doi.org/10.1002/hlca.200800390

18. H. Y. Alniss, N. G. Anthony, A. I. Khalaf, S. P. Mackay, C. J. Suckling, R. D. Waigh, N. J. Wheate, J. A. Parkinson, Chem. Sci., 2012, 3, 711-722.

http://dx.doi.org/10.1039/C2SC00630H

19. M.-V. Salvia, F. Addison, H. Y. Alniss, N. J. Buurma, A. I. Khalaf, S. P. Mackay, N. G. Anthony, C. J. Suckling, M. P. Evstigneev, A. H. Santiago, R. D. Waigh, J. A. Parkinson, Biophys. Chem., 2013, 179, 1-11. http://dx.doi.org/10.1016/j.bpc.2013.04.001

20. N. Anthony, D. Breen, G. Donoghue, A. I. Khalaf, S. P. Mackay, C. J. Suckling, Org. Biomol. Chem. 2009, 7, 18431850. http://dx.doi.org/10.1039/b901898k

21. W. Treesuwan, K. Wittayanarakul, N. G. Anthony, G. Huchet, H. Alniss, S. Hannongbua, A. I. Khalaf, C. J. Suckling, J. A Parkinson, R. D. Waigh, S. P. Mackay, Phys. Chem. Chem. Phys., 2009, 11, 10682-10693.

http://dx.doi.org/10.1039/b910574c

22. A. I. Khalaf, Curr. Trends Med. Chem., 2009, 6, 53-63.

23. J. G. Pelton, D. E. Wemmer, J. Am. Chem. Soc. 1990, 112, 1393-1399. http://dx.doi.org/10.1021/ja00160a016

24. (a) A. I. Khalaf, C. J. Suckling, R. D. Waigh, Heterocyclic carboxamide derivatives as minor groove binders of DNA and their preparation, pharmaceutical compositions and use in the treatment of bacterial, fungal and other microbial infections, PCT Int. Appl. 2008, WO2008038018 A1 20080403. (b) A. I. Khalaf, R. D. Waigh, C. J. Suckling, Preparation of oligopeptide DNA minor groove-ding compounds, PCT Int. Appl. 2003, WO2003059881 A2 20030724.

25. K. R. Fox, M. J. Waring, Method. Enzymol., 2001, 340, 412430. http://dx.doi.org/10.1016/S0076-6879(01)40434-4

26. S. Lang, A. I. Khalaf, D. Breen, J. K. Huggan, C. J. Clements, S. P. MacKay, C. J. Suckling, Med. Chem. Res., 2014, 23, 1170-1179. http://dx.doi.org/10.1007/s00044-013-0723-0

27. C. A. Lanteri, R. R. Tidwell, S. R. Meshnick, Antimicrob. Agents Ch., 2008, 52, 875-882. http://dx.doi.org/10.1128/AAC.00642-07

28. T. A. Shapiro, P. T. Englund, Proc. Natl. Acad. Sci. USA, 1990, 87, 950-954. http://dx.doi.org/10.1073/pnas.87.3.950

29. C. L. Gibson, J. K. Huggan, A. Kennedy, L. Kiefer, J.-H. Lee, C. J. Suckling, C. Clements, A. L. Harvey, W. N. Hunter, L. B. Tulloch, Org. Biomol. Chem. 2009, 7, 1829-1842. http://dx.doi.org/10.1039/B818339B

30. R. W. Burli, D. McMinn, J. A. Kaizerman, W. Hu, Y. Ge, Q. Pack, V. Jaing, M. Gross, M. Garcia, R. Tanaka, H. E. Moser, Bioorg. Med. Chem. Lett. 2004, 14, 1253-1257. http://dx.doi.org/10.1016/j.bmcl.2003.12.042

31. C. J. Suckling, J. Phys. Org. Chem. 2008, 21, 575-583. http://dx.doi.org/10.1002/poc. 1323

32. M. P. Barrett, C. G. Gemmell, C. J. Suckling, Pharmacol. Ther., 2013, 139, 12-23. http://dx.doi.org/10.1016/j.pharmthera.2013.03.002/

33. F. Brucoli, J. D. Guzman, A. Maitra, C. H. James, K. R. Fox, S. Bhakta, Bioorg. Med. Chem. 2015, 23, 3705-3711. http://dx.doi.org/10.1016/j.bmc.2015.04.001

34. J. D. Guzman, A. Gupta, F. Bucar, S. Gibbons, S. Bhakta, Front. Biosci., 2012, 17, 1861-1881. http://dx.doi.org/10.2741/4024

35. S. Deborggraeve, M. Koffi, V. Jamonneau, F. A. Bonsu, R. Queyson, P. P. Simarro, P. Herdewijn, P. Büscher, Diagn. Micr. Infec. Dis., 2008, 61, 428-433. http://dx.doi.org/10.1016/j.diagmicrobio.2008.03.006

36. W. Masocha, K. Kristensson, Virulence, 2012, 3, 202-212. http://dx.doi.org/10.4161/viru.19178

37. D. Legros, G. Ollivier, M. Gastellu-Etchegorry, C. Paquet, C. Burri, J. Jannin, P. Büscher, Lancet Infect. Dis., 2002, 2, 437-440. http://dx.doi.org/10.1016/S1473-3099(02)00321-3

38. W. C. Gibson, Int. J. Parasitol. 2007, 37, 829-838. http://dx.doi.org/10.1016/j.ijpara.2007.03.002

39. J. J. Joubert, C. H. Schutte, D. J. Irons, P. J. Fripp, T. Roy. Soc. Trop. Med. H., 1993, 87, 494-495. http:dx.doi.org/10.1016/0035-9203(93)90056-v

40. G. C. Cook, T. Roy. Soc. Trop. Med. H., 1994, 88, 257-258. http://dx.doi.org/10.1016/0035-9203(94)90068-X

41. J. J. Kelly, E. E. Baird, P. B. Dervan, Proc. Natl. Acad. Sci. USA, 1996, 93, 6981-6985. 
http://dx.doi.org/10.1073/pnas.93.14.6981

42. C. J. Suckling, Chem. Biol. Interface, 2015, 5, 166-174.

43. J. A. Parkinson, F. J. Scott, C. J. Suckling, G. Wilson, Med. Chem. Commun. 2013, 4, 1105-1108. http://dx.doi.org/10.1039/c3md00071k

44. A. I. Khalaf, N. Anthony, D. Breen, G. Donoghue, S. P. MacKay, F. J. Scott, C. J. Suckling, Eur. J. Med. Chem., 2011, 46, 5343-5355.

http://dx.doi.org/10.1016/j.ejmech.2011.08.035

45. F. J. Scott, M. Puig-Sellart, A. I. Khalaf, C. J. Henderson, G. Westrop, D. G. Watson, K. Carter, M. H. Grant, C. J. Suckling, Bioorg. Med. Chem. Lett. 2016, 26, 3478-3486. http://dx.doi.org/10.1016/j.bmcl.2016.06.040

46. F. J. Scott, A. I. Khalaf, F. Giordani, P. E. Wong, S. Duffy, M. Barrett, V. M. Avery, C. J. Suckling, Eur. J. Med. Chem., 2016, 116, 116-125. http://dx.doi.org/10.1016/j.ejmech.2016.03.064

47. M. Sands, M. A. Kron, R. B. Brown, Rev. Infect. Dis., 1985, 7, 625-634. http://dx.doi.org/10.1093/clinids/7.5.625

48. A. M. W. Stead, P. G. Bray, I. G. Edwards, H. P. de Koning, B. C. Elford, P. A. Stocks, S. A. Ward, Mol. Pharmacol., 2001, 59, 1298-1306.

49. M. Lavesa, K. R. Fox, Anal. Biochem., 2001, 293, 246-250. http://dx.doi.org/10.1006/abio.2001.5124

50. P. Cozzi, N. Mongelli, Curr. Pharm. Design, 1998, 4, 181-201.

51. F. Scott, A. I. Khalaf, S. Duffy, V. M. Avery, C. J. Suckling, Bioorg. Med. Chem. Lett. 2016, 26, 3326-3329. http://dx.doi.org/10.1016/j.bmcl.2016.05.039

52. http://www.who.int/malaria/areas/drug_resistance/overview/en/ 53. A. M. Dondorp, F. Nosten, P. Yi, D. Das, A. Phae Phyo, J. Tarning, K M. Lwin, F. Ariey, W. Hanpithakpong, S. J. Lee, P. Ringwald, K. Silamut, M. Imwong, K. Chotivanich, P. Lim, T. Herdman, S. S. An, S. Yeung, P. Singhasivanon, N. P. J. Day, N. Lindegardh, D. Socheat, N. J. White, New Engl. J. Med., 2009, 361, 455-467. http://dx.doi.org/10.1056/NEJMoa0808859

54. B. Baragana, I. Hallyburton, M. C. S. Lee, N. R. Norcross, R. Grimaldi, T. D. Otto, W. R. Proto, A. M. Blagborough, S. Meister, G. Wirjanata, A. Ruecker, L. M. Upton, T. S. Abraham, M. J. Almeida, A. Pradhan, A. Porzelle, M. S. Martínez, J. M. Bolscher, A. Woodland, T. Luksch, S. Norval, F. Zuccotto, J. Thomas, F. Simeons, L. Stojanovski, M. Osuna-Cabello, P. M. Brock, T. S. Churcher, K. A. Sala, S. E. Zakutansky, M. B. Jiménez-Díaz, L. M. Sanz, J. Riley, R. Basak, M. Campbell, V. M. Avery, R. W. Sauerwein, K. J. Dechering, R. Noviyanti, B. Campo, J. A. Frearson, I. Angulo-Barturen, S. Ferrer-Bazaga, F. J. Gamo, P. G. Wyatt, D.
Leroy, P. Siegl, M. J. Delves, D. E. Kyle, S. Wittlin, J. Marfurt, R. N. Price, R. E. Sinden, E. A. Winzeler, S. A. Charman, L. Bebrevska, D. W. Gray, S. Campbell, A. H. Fairlamb, P. A. Willis, J. C. Rayner, D. A. Fidock, K. D. Read, I. H. Gilbert, Nature, 2015, 522, 315-320.

http://dx.doi.org/10.1038/nature14451

55. H. Turner, Future Med. Chem., 2016, 8, 227-238. http://dx.doi.org/10.4155/fmc.15.177

56. C. W. McNamara, M. C. S. Lee, C. S. Lim, S. H. Lim, J. Roland, A. Nagle, O. Simon, B. K. S. Yeung, A. K. Chatterjee, S. L. McCormack, M. J. Manary, A.-M. Zeeman, K. J. Dechering, T. R. S. Kumar, P. P. Henrich, K. Gagaring, M. Ibanez, N. Kato, K. L. Kuhen, C. Fischli, M. Rottmann, D. M. Plouffe, B. Bursulaya, S. Meister, L. Rameh, J. Trappe, D. Haasen, M. Timmerman, R. W. Sauerwein, R. Suwanarusk, B. Russell, L. Renia, F. Nosten, D. C. Tully, C. H. M. Kocken, R. J. Glynne, C. Bodenreider, D. A. Fidock, T. T. Diagana, E. A. Winzeler, Nature, 2013, 504, 248-254.

http://dx.doi.org/10.1038/nature12782

57. M. A. Phillips, J. Lotharius, K. Marsh, J. White, A. Dayan, K. L. White, J. W. Njoroge, F. El Mazouni, Y. Lao, S. Kokkonda, D. R. Tomchick, X. Deng, T. Laird, S. N. Bhatia, S. March, C. L. Ng, D. A. Fidock, S. Wittlin, M. Lafuente-Monasterio, F. J. Gamo Benito, L. M. Sanz Alonso, M. S. Martinez, M. B. Jimenez-Diaz, S. F. Bazaga, I. Angulo-Barturen, J. N. Haselden, J. Louttit, Y. Cui, A. Sridhar, A.-M. Zeeman, C. Kocken, R. Sauerwein, K. Dechering, V. M. Avery, S. Duffy, M. Delves, R. Sinden, A. Ruecker, K. S. Wickham, R. Rochford, J. Gahagen, L. Iyer, E. Riccio, J. Mirsalis, I. Bathhurst, T. Rueckle, X. Ding, B. Campo, D. Leroy, M. J. Rogers, P. K. Rathod, J. N. Burrows, S. A. Charman, Sci. Transl. Med., 2015, 7, 296 ra111. http://dx.doi.org/10.1126/scitranslmed.aaa6645

58. K. Werbovetz, Curr. Opin. Investig. D., 2006, 7, 147-157.

59. M. M. Aleksić, V. Kapetanović, Acta Chim. Slov., 2014, 61, 555-573.

60. R. Vafazadeh, N. Hasanzade, M. M. Heidari, A. C. Willis, Acta Chim. Slov., 2015, 62, 122-129. http://dx.doi.org/10.17344/acsi.2014.797

61. G. S. Khan, L. I. Pilkington, D. Barker, Bioorg. Med. Chem. Lett. 2016, 26, 804-808.

http://dx.doi.org/10.1016/j.bmcl.2015.12.090

62. S. P. Gupta, P. Pandya, G. S. Kumar, S. Kumar: Indole Derivatives as DNA Minor Groove Binders, in: Chemistry of Phytopotentials: Health, Energy and Environmental Perspectives. Eds. L. D. Khemani, M. M. Srivastava, S. Srivastava, 2012, pp. 149-153. http://dx.doi.org/10.1007/978-3-642-23394-4 


\section{Povzetek}

Mnogi avtorji so raziskovali sinteze in biološke aktivnosti različnih analogov distamicina A, ki je naravna učinkovina proti bakterijam in glivam. Odkriti analogi so bili uporabljeni pri različnih bioloških testiranjih; nekateri so se izkazali kot zelo aktivni proti različnim Gram-pozitivnim in Gram-negativnim bakterijam ter tudi proti glivam. Da bi lahko raziskovali tudi njihovo aktivnost proti parazitom, je bilo potrebno izvesti nekatere specifične modifikacije. Mnoge izmed tako spremenjenih spojin so se izkazale kot učinkovite proti Trypanosoma brucei. Z uporabo študije iskanja odtisov in NMR spektroskopijo smo raziskali vezavo mnogih tovrstnih spojin na kratke odseke DNA. Da bi razumeli načine, kako se te spojine vežejo na specifične odseke DNA, smo na primerih izbranih spojin uporabili računalniško modeliranje. Na standardni učinkovini distamicin smo izvedli mnoge variacije, ki so vključevale zamenjavo pirolskega obroča in tudi končnih skupin (na glavi in repu spojine) z mnogimi različnimi heterocikličnimi fragmenti. Nekatere izmed teh spojin, ki se vežejo na mali žleb (MGB), smo raziskali kot potencialne učinkovine proti raku, zlasti proti raku na pljučih. 